\title{
Teacher education as a laboratory for developing teaching approaches-a collaboration between teacher educators, student teachers, and local schools
}

\author{
Birgitte Lund Nielsen $^{1}$ (D) Elsebeth Jensen ${ }^{1}$
}

Received: 15 October 2020 / Accepted: 6 October 2021

(c) The Author(s), under exclusive licence to Springer Nature Singapore Pte Ltd. 2021

\begin{abstract}
The paper presents research from a Danish large-scale and collaborative initiative for systematically developing teacher education 'Teacher education as a laboratory for developing excellent teaching and education' (LULAB). Framed by this initiative, local teacher educators and student teachers are, in collaboration with teachers and students from partner-schools, experimenting with developing, analyzing, and sharing teaching approaches in teacher education. Hence, LULAB is an institutional strategic top-down initiative aimed to support the development of professional skills among student teachers and teacher educators, with supportive leadership for bottom-up changes from the microlevel projects. Inspired by designbased research, the findings are used iteratively to inform the organization of LULAB. Data are collected following a sequential mixed methods strategy, with questionnaires and multiple qualitative data. Findings from the first year of the LULAB initiative indicate a growing awareness among teacher educators about the co-developing role of student teachers being something distinctive for LULAB. Both teacher educators and student teachers emphasize their perceived professional outcomes. The student teachers refer in particular to insights from being invited into the machine room of teacher education and inspiration for their future work as teachers. However, there are also challenges involved in developing a culture of inquiry, and possibilities for support from the leadership looking forward are discussed.
\end{abstract}

Keywords Teacher education · Learning communities · Professional inquiry · Organizational learning

\section{Introduction}

The work as a teacher educator is a particular profession, and teacher educators' need for professional development are rather new areas of interest in educational research (Czerniawski et al., 2017; Lunenberg et al., 2014). Collaborative professional learning communities have been discussed in school development for some years and recently, also concerning

$\bowtie$ Birgitte Lund Nielsen

BLN@via.dk

1 VIA University College, Aarhus, Denmark 
teacher educators' professional learning (Brody \& Hadar, 2015). Boyd and White (2017) discuss teacher educators' professional inquiries, organized in learning communities, and position professional inquiry on an axis between evaluating teaching and genuine practitioner research. The need for developing teacher education and professional learning among teacher educators, i.e., through professional inquiry, is one part of the rationale for initiating the Danish initiative framing the research in the present paper: 'Teacher education as a laboratory for developing excellent teaching and education.' We use the acronym LULAB, which is short for the title in Danish. Another, and likewise important part of the rationale focuses on the student teachers' learning, referring to a recent national evaluation of teacher education (policy document 12018 ) and ten policy ambitions, where number ten is to develop teacher education as a laboratory for good education (policy document 2 2018). The external evaluation points to a satisfactory level of content and pedagogical knowledge among the novice teachers. However, the school leaders, as employers, ask for more focus on concrete professional skills. The graduates themselves ask for more variation in the teaching in teacher education and more focus on practice-related skills. Hence, the vision of LULAB is to support both, (1) the development of professional skills among student teachers and (2) teacher educators' professional learning and collaboration. Furthermore, as a systemic initiative, LULAB is also targeting (3) teacher education as an organization, and organizational learning (Schein, 2017).

So, LULAB refers to a national policy, but decisions about how to implement it at our teacher education institution, one of the largest in Denmark with teacher education at four addresses and 2800 student teachers enrolled, were made locally by the leadership. An organizing team with representation from leadership, research, and teacher educators is in charge of developing the organizational frames and describing the research-informed criteria for a LULAB project. In so far, two rounds in 2019 and 2020 teacher educators have applied for LULAB projects, typically 2-3 working together with one or more classes of student teachers, and in many cases also with in-service teachers. The process led to grants for 23 LULAB projects starting in August 2019 and for additionally 17 new projects initiated in August 2020. The LULAB initiative is financed until 2023, so more rounds of applications will follow. Data presented and discussed in this paper are from the first year of the longitudinal initiative. These pilot data are used iteratively to inform the continuing development (Fig. 1).

The criteria for getting a grant for a LULAB project (Fig. 2) are informed by research about how to organize and develop teacher education. This research field is quite complex.

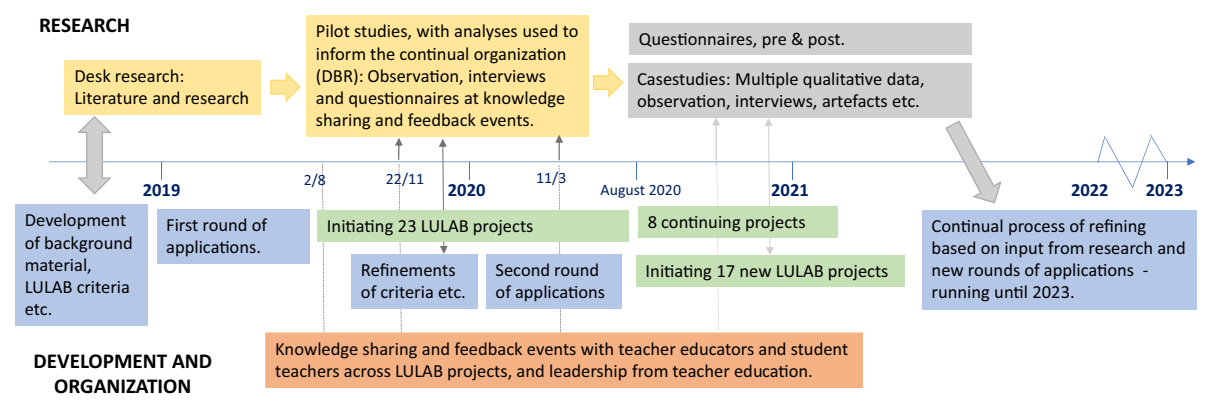

Fig. 1 An overview of development and research in the LULAB initiative. The paper presents findings from the pilot studies, in the first year, with a particular focus on data from two knowledge-sharing events 
- LULAB is about educational development

- The project must refer to the overall vision of teacher education as a center for educational development, in particular in relation to teaching and learning approaches supporting participation and active involvement among the student teachers.

- Including the double perspective of educating someone who are going to teach themselves.

- An iterative development is described

- The approach is experimental/inquiry: 'something' is developed, designed/re-designed, implemented and systematically documented, evaluated/ analyzed, and further developed (new iteration), taking actions for change based on what was learned through the process.

- There is a clear substantiation

$\circ$ referring to theory and research and/or experiences from the teacher education context (needs, possibilities, challenges, demands).

- It opens possibilities for innovation - doing something that we do not already do - but with the potential of a sustainable and resource-neutral institutionalization.

- It happens in collaboration

$\circ$ It is about professional skills and learning - with developmental possibilities for both teacher educators and student teachers.

- This means, collaboration between teacher educators and student teachers, more than one teacher educator and/or with other external stakeholders.

- There is a reference to professional practice

- Something student teachers are doing at the school arena can be the object in (parts of) the project, or it can happen in collaboration with stakeholders from schools.

Fig. 2 The LULAB criteria. In the material for the application, the LULAB criteria are elaborated and substantiated, referring to some of the background research also in this paper

There is no simple way to answer the question about how best to organize teacher education, among other things, because the programs in various countries are organized very differently and are hard to compare (Cochran-Smith \& Zeichner, 2005). Internationally there are many postgraduate programs, e.g., 1-year programs with pedagogy and internships where the student teacher enters with one or more subject degrees. Nevertheless, there are also integrated programs. Furthermore, teacher education programs differ between being primarily university-based or primarily school-based.

In Denmark, teacher education for primary and lower secondary is organized as integrated 4-year professional bachelor programs during which the student teachers work with pedagogy, school subjects, and internships. The main part of the education is at the college, but the intention is to work closely with schools also beyond the yearly internships. Nevertheless, despite the complexity, there is a kind of consensus about some principles for quality teacher education, including involving student teachers in active and focused inquiries into teaching and learning situations (Dobber et al., 2012; Klette \& Hammerness, 2016). We also in Danish teacher education include projects where the student teachers are making inquiries at schools, e.g., during their BA project, in some cases in cooperation with local teachers (Nielsen et al., 2018). Student teachers' inquiries at schools are, however, in this example like in the large amount of international research focused on developing the teaching in schools. The particular focus in LULAB is the cooperation between teacher educators and student teachers focused on developing the teaching in teacher education. The intention is certainly not to replace the professional inquiries at schools; this is still prioritized and is also a part of some LULAB projects. The LULAB initiative, however, has the teaching at the college as the starting point and particular focus. The rationale for doing so is based on the particular feature of teacher education, which is that the aim of learning to teach also is addressed in the practice of teacher education. Hence, the aims and the means coincide at an overall level. We know from research that the level to which the teacher educators can explicate and can experiment in their own teaching (implicit and explicit modeling) can be determent for the student teachers' outcomes (Lunenberg et al., 2014). Therefore, we in LULAB and 
other developmental initiatives refer to 'second-order teaching' when discussing teaching in teacher education.

Summing up, the LULAB initiative is addressing a gap by examining cooperation between teacher educators and student teachers in inquiry projects targeting approaches in teacher education in particular. In this context, the research, as it will be substantiated in the following sections, is examining potentials and constraints both as experienced by the professionals (teacher educators and student teachers), and as observed when examining their professional dialogues, discussing these data in the context of organizational change in teacher education.

\section{Background}

\subsection{Professional inquiry and scholarly approaches}

In LULAB, the term 'laboratory' is used in a Dewey inspired understanding (Staunæs et al., 2014) describing the vision of developing teacher education through collaborative experiments. Cochran-Smith and Lytle (2009) refer to what they call 'inquiry as a stance.' They see inquiry as more than the sum of its parts (developing questions, collecting and analyzing data, sharing results, and taking actions for change based on what was learned through the process). Instead, inquiry is a worldview and a habit of mind - the perspective through which questions and observations are interpreted (Cochran-Smith \& Lytle, 2009). Likewise, Dana (2015) differs between inquiry as stance and inquiry as project, warning against approaching inquiry just as a linear stepwise process in a particular project. Dana (2015) and CochranSmith and Lytle (2009) refer in particular to teachers and inquiries at schools. However, this thinking about inquiry as ongoing iterative processes, working together to bring about educational change grounded in the problems and the contexts of practice, is likewise relevant in teacher education (Tack \& Vanderlinde, 2014). Hence, practitioner inquiry is basically about acknowledging practitioners' questioning and narratives (Cochran-Smith \& Lytle, 2009). In LULAB, both teacher educators, student teachers, and partners from schools are seen as 'practitioners' in teacher education. Darling-Hammond (2005) emphasizes that educational change depends on initiatives at different levels of the system and that most successful reform initiatives are those that induce top-down support and input of new ideas at the same time supporting bottom-up development. With these terms, LULAB is a top-down strategic initiative aimed to support professional learning among teacher educators and student teachers, but in an approach with supportive leadership for bottom-up changes. Hence, to follow the impact of the initiative the voices of the practitioners are essential. Boyd and White (2017) define professional inquiry as a middle position between the reflected development of teaching based on evaluation and genuine practitioner research. The professional inquiry includes some kind of systematic documentation of changing classroom practices and stakeholders' learning. In the research literature about higher education, there is a broad base of literature referring to scholarly approaches to develop teaching, under the headline of the scholarship of teaching and learning (SoTL) (Cranton, 2011). SoTL is about collaborative inquiries into own practice and student learning, with both systematic observation and theoretically informed analyses, based on the principles that sustainable changes must be owned by the practitioners and that informed discussion and documentation is determent to develop a quality culture. Mårtensson et al. (2011) emphasize that SoTL is not just an approach to developing teaching in the individual classroom but even more important an organizational strategy at the university cultivating a culture of continuous improvement of teaching and learning. Thus, 
the perspectives from the practioners must be interpreted also in light of the potentials and constraints regarding the organizational culture.

\subsection{Organizational learning}

The term 'organizational learning' addresses the process, where the culture in an organization is changing, with culture, as defined by Schein (2017), being the accumulated patterns of beliefs, values, and behavioral norms that come to be taken for granted. According to Weick (1995), organizational learning is not just about developing new procedures, but rather about supporting meaning for the stakeholders organically adapting the organizational procedures. Across research, there are a range of ways to define and understand organizational learning, but as emphasized based on a review (Wang \& Ahmed, 2003), it is more than the sum of the stakeholders' learning; it is about the interaction between stakeholders and in the organization as a whole. Schein (2017) identifies what a learning culture might look like, including proactivity, commitment to 'learning to learn,' and inquiry and dialogue and commitment to systemic thinking (Schein, 2017: 344). Learning-oriented leadership requires setting an appropriate example and abandoning a simple linear causal logic acknowledging the complex, nonlinear and interconnected processes being part of sense-making in a group (Weick $\&$ Sutcliffe, 2001). Professional dialogues are emphasized in the literature about professional learning communities referred to above (Hadar \& Brody, 2010), but also as part of organizational learning: 'Opening space for the creation of shared meaning, reconstituting power relations, providing cultural tools to mediate learning' (Boreham \& Morgan, 2007). Hökkä et al. (2008) and Hökkä and Eteläpelto (2014) examining teacher educators' workplace learning likewise emphasize the learning communities as crucial in supporting the individual's professional agency and that this requires visionary leadership, timing, and structural support. Therefore, the research in the context of the LULAB initiative is examining both the meaning and perspectives of the professionals involved, the professional dialogues among them, and the inferred implications regarding the organizational culture.

\section{Research question}

RQ1: What kind of projects are initiated in the frames of the LULAB initiative? RQ2: What are the outcomes from the first year of this longitudinal initiative:

- as inferred based on observing the professional dialogues at knowledge-sharing events?

- as perceived by the teacher educators and student teachers involved?

RQ3: What potentials and constraints concerning developing the culture in teacher education can be identified based on the findings regarding RQ1 and RQ2?

\subsection{Methods}

The research design is inspired by the principles of design-based research (DBR) (Barab \& Squire, 2004). As illustrated in Fig. 1, the first design of the LULAB organization and criteria was informed by research, and likewise, there are repeated refinements along the project period (2019-2023). Hence, the findings from the first year of the LULAB initiative are incorporated to develop the organizational framing and the next steps in the research iteratively. In the frames of the DBR-design, data are collected following an emergent sequential 
mixed methods strategy (Creswell \& Clark, 2018) with the main focus on qualitative data. Changing the culture in an organization is expected to be a process over a longer time, but the initiation phase can give some indication if we, so to say, are on the right track. With this aim, interviews were made with teacher educators and student teachers from LULAB projects. The first results are presented in a previous publication (Nielsen, 2020) but summed in case descriptions (RQ1). To answer RQ2 data from two knowledge-sharing and feedback arrangements is analyzed. Data from the first of these two events include observation, interviews, and reflections from student teachers and teacher educators. Both internal members of the LULAB organizing team and external observers participated to be able to observe all feedback sessions regarding the 23 projects. Teacher educators and 1-2 student teacher representatives from each project participated in the peer feedback. Observations were made following a structured protocol organized under headlines of the criteria (Fig. 2) and as a full-text memo. The observations targeted how the projects were discussed at the day, not the quality of things developed per se. At the end of the day all participants furthermore contributed with written reflections. Data analysis followed the procedures of thematic analysis (Braun \& Clarke, 2006).

Data from the second of the two events, with participants also beyond the concrete LULAB projects, are from a questionnaire with both Likert scale categories and open reflections, asking the professionals about the critical points from the dialogues and about how the LULAB initiative are perceived to affect the development of teacher education and their own professional learning. These data must be interpreted with caution. Due to the Covid-19 lockdown spring 2020, we only have data from a part of the teacher educators, so percentages below are based on 18 answers (16\%), however, representatively divided on years of experience in teacher education and with $44 \%$ themselves involved in a LULAB project and $56 \%$ not yet in a concrete project. The data from the questionnaire have been analyzed by frequency analysis and cross-tabulations, and the open reflections have been thematized (Braun \& Clarke, 2006).

\subsection{Findings}

The first section of the findings provides an overview of the types of LULAB projects, elaborating on two cases from the range of projects to answer RQ1. This is followed by presenting data from two knowledge-sharing events (RQ2), initiating after this the discussion about the organizational perspective (RQ3), based, e.g., on the tensions emphasized in the thematic analysis regarding RQ2.

\subsection{The types of LULAB projects}

In general, a vast range of themes are addressed in the LULAB projects (an overviewis presented in Nielsen, 2020). The application process has, besides the professional inquiry approach mirrored in the criteria (Fig. 2), not been guided by themes decided beforehand from the leadership. Hence, diversity is the first observation. There are, however, also some themes addressed across projects, for example, how to develop the study culture to be more ambitious - a challenge discussed in policy documents 1 and 2. Furthermore, several projects are addressing the classical teacher education issue about school practice and cooperation across arenas, with examples of simulation-like activities where student teachers microteach small groups of students and reflect and analyze the experiences as a part of planning for the longer internship. A range of other projects are addressing new twenty-first century challenges, for example, in relational to integrating technology in teacher education. The two 
cases which are both presented in more details in Nielsen (2020) are sampled to illustrate the microteaching mentioned and also another theme repeated in more than one project, namely professional reflection in teacher education with the use of video. The approach in the two projects differ, focusing on the competence as (new) students in higher education in the first case, and the competence as future teachers in the second case, but the critical point is that the work is inspired both by international teacher education research (Barnhart \& van Es, 2015; Stockero, 2008). The teacher educators involved in the two cases differ with young assistant professors and temporary lecturers in the first case and experienced associate professors in the second case. Across projects, there is also this variation in experience of the teacher educators involved.

\subsection{Case 1: video-log (V-log) at first year}

This one-semester project was substantiated, referring to experiences of the insecurity among student teachers starting at teacher education. The project intended to develop a safe platform for reflection on study-strategies. Three teacher educators and three classes of first-year student teachers worked in the project aimed to develop in particular the cooperative practice in the study groups, as this based on the literature and evaluation from former student teachers are expected to support the individual students and mediate the collaborative professional learning process. The idea of working with video logs (sharing short 2-4 min videos) was concretized throughout the semester in collaboration between the teacher educators and the novice student teachers. Along the semester were three iterations with reflective tasks for the V-log, the first task was in short about expressing expectations for the work in the study group and making a group contract, the next an individual task of recording a reflection about strategies for studying, and the third task was a group dialogue about the progress in the collaboration in the study group, followed by an individual reflection. As outcomes from the project, the teacher educators emphasize a more in-depth insight into the student teachers' thoughts and motives, that V-log has also given the quieter and more insecure student teachers 'voice.' For the student teachers, this was a just-in-time approach as they as new students were concerned with finding out about the norm culture and the demands and expectations from the education. They expressed that they from the start saw the study group as a safe-spot and a kind of home base, and refer positively to the demands of making a collaborative contract and, though they, of course, have not tried how it would have been without V-log they acknowledge and recommend the continual use of the log. This LULAB is now finished, but the approach will be used at next year's classes of first-year students. The recommendation based on the evaluation is to additionally work with study strategy about how to approach the literature, also involving student assistants, and to use the V-logs also in the first internship.

\subsection{Case 2: the triad of teacher education}

The triad of teacher education is a term being used in Denmark to describe teacher education as anchored in the three categories of knowledge, (1) the school subjects, here science, (2) the pedagogical subjects, and (3) the school practice/internships. ${ }^{1}$ The project was substantiated, referring to the need they experienced for synthesis across these areas of knowledge in teacher

1 School practice is a subject of its one in teacher education in Denmark, with intended learning outcomes, exams, etc. 
education and referring also to research about dialogic teaching and the possibility for the student teachers to train their skills in this area. The ambition was to work with 2nd-year student teachers' professional skills, using video to give them the possibility to practice, reflect on, and analyze their own teaching and students' learning. The project covered two semesters. The focus in the first iteration was how to mediate dialogue in a science class and pose the productive questions. Teachers and students from a local school were involved visiting teacher education, so the student teachers had the chance to try out microteaching with more than one group of school students in the science laboratory at the campus. After this first trial, the videos were analyzed on campus as part of teaching for both subject and pedagogy. In the next iteration, the experiences were used in planning for and videotaping from their own teaching in the internship in the 2 nd semester. Here the collaborative video analyses in groups of student teachers (video-clubs) were further developed based on the first experiences. This project is still running. The teacher educators experienced that the professional reflections among these student teachers were qualified compared to other 2nd year classes. They also reflected on how to develop activities looking forward, including the possibility for a more active role for the in-service teachers bringing the school students to the campus. As it was, they were mainly spectators. The student teachers emphasized in particular outcomes from the microteaching event with the school students. Furthermore, they referred positively to the structured scaffolding of their video analyses and the progression from the first to the second task. They also emphasized as the student teachers, in general, do (more below), that it is exciting to be a part of what they call 'the machine room' of developing approaches in teacher education.

\subsection{Knowledge sharing, dialogues, and peer feedback}

Now we continue to data from two knowledge-sharing events. Professional dialogues also across projects were prioritized from the initiation in August 2019. Here we refer to data from two larger events, first a full-day event for teacher educators and student teachers in November 2019 with dialogue and peer feedback across projects. The participants were, as it will be elaborated below, very positive about the outcomes from this day. However, some of them emphasized the need to involve also colleagues not at the moment part of a concrete LULAB project. Referring to the DBR approach, findings from the research are used to continuingly redesign the actions taken and the support provided, and based on this feedback an event with dialogue and knowledge-sharing with the rest of the teacher educators was planned in March 2020. This is the second event referred to below.

\subsection{Peer feedback across LULAB projects November 2019}

All in all, around 80 teacher educators, student teachers, and leaders participated in this event. First, there were short presentations about giving feedback as the starting point for reflection, dialogue, and learning. Then feedback was organized in groups of three projects. The projects themselves had in advance identified questions where they asked for feedback. In between, there was also an aquarium-session with feedback from participants from one project and the rest of the participants as reflective teams.

From the analysis of the rich observations, two particular themes emphasizing areas of tensions emerged.

Theme 1 The presentations and the feedback asked for focused on what had been done in the projects more than on the iterative elements, the consequences, and the next steps. However, 
some projects appeared to be more innovative than others concerning this iterative dimension, and also concerning the other criteria (Fig. 2) being recognizable in the presentation of the project and the requests for feedback. This fact was clear based on both the structured observations, noting, e.g., how the criteria appeared in the dialogues, but also in the memo reflections. Some of the observers emphasized spontaneously the sense of something new happening here in their memo reflections because of the way discussions were framed. At the same time, they in other sessions noted that this was very much like 'a normal event,' with a teacher educator describing something that had been done. Hence, concerning 'an inquiry stance' there appears to be sizeable across-project variation.

Theme 2 The other major theme was about the role of the student teachers, both the role taken by the participating student teachers and the role given in the projects. The role of the student teachers as collaborative partners is emphasized in the criteria (Fig. 2). Several observations noticed the engagement of the student teachers both in the shared sessions and in the group sessions. Moreover, there were indications that the student teachers experienced a possibility for transfer. For example, there was one student teacher making many notes during the initial presentation about feedback. She afterward explained to an observer that this was very useful concerning a project she was working on about feedback in a school context. However, there were also observations from parallel sessions where the student teachers from a specific project asked questions and came with ideas during the feedback that might have been used in the development if they had a clearer role as co-developers. Hence, there were indications that student teachers were mainly constituted in the traditional role of students.

\subsection{Student teachers' perceived outcomes}

In the reflections about perceived outcomes, the student teachers were, however, very positive. They emphasized an experience of being involved and listened to: 'It is cool as a student teacher to be involved because it is great to feel you are listened to, and this feeling is spreading among our co-students.' They furthermore referred to transfer to the school context directly: 'The LULAB approach could, with advantage, be in all the teaching [in teacher education] because this is how we are going to work as future teachers,' and by calling the LULAB projects practice-oriented: 'The LULAB projects are practice-oriented, and this is to a high degree in demand among us student teachers.' Furthermore, they reflected on learning from being involved in professional feedback: 'It is really interesting to hear about the reflections and thoughts among the teacher educators. You are getting aware [as a student teacher] what sparring and feedback can do in teaching and inquiry projects and the importance of thinking in new ways and listen to the perspectives from colleagues.'

The reflections from the student teachers, though being very positive, however, also indicated the same as seen in the observations, that the teacher educators were the ones getting the feedback: 'Curt [a teacher educator in the concrete LULAB project] got ideas from the feedback and sparring from the others that he would never have gained alone...'. This quote indicates that the student teachers did not in all projects see themselves as genuine project participants.

Teacher educators and leaders also contributed with reflections on their perceived outcomes, and they were also quite positive. The next section will focus in particular on the teacher educators, here just one quote about the transfer issue in a professional learning perspective: 'It is a part of the DNA of teacher education that we are all the time concerned with developing and qualifying the learning-processes to educate well-qualified teachers. 
This represents a process of "Bildung"- an approach to professional learning where we are experimenting and exploring together.'

\subsection{Professional dialogues with teacher educators also beyond the concrete projects}

The need for events sharing knowledge also with colleagues not at the moment part of a LULAB project was as mentioned raised in the reflections at the November event, stating that this was so important that every colleague should be a part of it. At a following event, March 2020, only teacher educators participated as it was arranged at a 2 days out of college yearly arrangement. The teacher educators were divided into groups by free choice sharing and discussing in a structured dialogue under the headline of themes addressed in LULAB projects. The themes were formulated in a generic form, so it was framed not as a one-way presentation from the colleagues in the LULAB projects but with experiences also from other colleagues being included in the dialogues. The aim was to stimulate the transfer between LULAB projects and the general practice in teacher education. Just after the group dialogues, the teacher educators filled in the questionnaire. In the reflections about key learning points, several teacher educators explicitly mentioned the student teachers as active co-developers as a key feature of LULAB: 'I have, in particular, noticed the possibilities in LULAB for student teachers to concretely being actors in the process of developing teaching. Often we only speak about, not act on, that student teachers should be developing education.' This teacher educator emphasized as something new in the LULAB context that the student teachers were involved in developing teaching. Hence, she differs between teaching (including planning and evaluating teaching), which the student teachers for example do in their yearly internships, and this about developing teaching iteratively (professional inquiry). This point was raised in more reflections, and it can be cautiously inferred that the role of student teachers as codevelopers has grown to be more acknowledged by the teacher educators along the first year, as it was not an issue during the first event.

\subsection{Teacher educators' perceived outcomes}

In general, the teacher educators in the questionnaire were positive in relation to LULAB both as an approach to organizational development and as affecting their own professional learning. Concerning how LULAB as an organizational initiative contributes to the development of teacher education, $50 \%$ answered 'to a very high degree,' $21 \%$ 'to a high degree,' $14 \%$ 'to some degree,' $14 \%$ 'to a smaller degree,' and $0 \%$ 'to a minimal degree or not at all.'

In the open reflections they referred to the bottom-up approach: 'It is an organized bottomup. Those who notice something important, and are engaged in these particular issues, have the chance to develop in that area.' The teacher educators also emphasized professional inquiry (Boyd \& White, 2017): 'I think, that the middle position between the normal development of your teaching and research is good, including the concrete nature of this project' and 'I get the possibility to inquire into and develop new professional knowledge.' Furthermore, the professional dialogues were valued, as a way to develop a shared language: 'It is terrific to share experiences with others. We are in the process of developing a shared language.'

In relation to how to use each other's ideas, one of the teacher educators emphasized collaborative planning of teaching: "We, in particular, exchange ideas when we collaborate about a concrete educational task. Nevertheless, I expect that the experiences shared from other LULAB projects will be an inspiration in such concrete collaboration, planning to teach together." 
Concerning the effect of LULAB on their professional learning, there is, as expected, a difference between those who are themselves involved in a concrete project and those who are not. In the full poll, 31 answers 'to a very high degree,' $15 \%$ 'to a high degree,' $31 \%$ 'to some degree,' $8 \%$ 'to a smaller degree,' $8 \%$ 'to a minimal degree or not at all,' and 7\% do not know. Among those being in a LULAB project themselves, this is $67 \%$ to a very high degree, $17 \%$ to a high degree, and $16 \%$ to some degree. Thus, teacher educators in LULAB projects in particular emphasize their outcomes: 'this is most certainly supporting my professional learning.' They refer to collegial collaboration: 'I have the possibility of collaborating with colleagues,' and: 'It is crucial with time for depth of spirit and development in collaboration with colleagues. We do in general [as teacher educators] not have much time for that.'

Among those teacher educators, not part of a concrete LULAB project, were some other kinds of reflections. They referred to vicarious experiences: 'LULAB has contributed most to my professional learning in the cases, where the colleagues I cooperate with daily are themselves inspired by their LULAB project, and bring that into our work.' The ideas behind the LULAB initiative were acknowledged also by these teacher educators: 'LULAB is a good initiative that needs to continue and be further developed. It is crucial with the anchoring in teacher education and the challenges experienced by the participants.' But they emphasized the need to have hand-on in a project yourself: 'The idea is really good, but it can be hard to feel the effect when not in a project yourself. Engagement and responsibility grow when you are creating yourself, and when you have a deep insight into the initiatives of others.'

\section{Discussion}

Summing up on the findings, the kind of projects initiated in the frames of the LULAB initiative are very diverse, but with some common themes informed by research in teacher education, here exemplified referring to student teachers' video-mediated professional reflections (Barnhart \& van Es, 2015; Stockero, 2008) and the use of microteaching simulations. Both features were intended for supporting student teachers concrete professional skills. Concerning the outcomes from the first year of this longitudinal initiative the professional practitioners, both teacher educators and student teachers referred to a high level of professional outcomes, for the student teachers in particular from being part of the machine room of teacher education, as they stated it themselves, and for the teacher educators in particular from the collaboration close to the teaching. Hence, in relation to the potentials and constraints concerning developing the culture in teacher education, the immediate engagement from the teacher educators and student teachers must be seen as a clear potential. This engagement and ownership are something that needs to be further supported and stimulated looking forward.

The two cases and the participants' reflections on outcomes illustrate the bottom-up approach (Darling-Hammond, 2005) where the practitioners' questioning and narratives are acknowledged. In this sense, there are indications of what Schein (2017) calls a learning culture, in particular among teacher educators in their everyday collaborations. Schein (2017) uses the direct reference to DNA, like one of the teacher educators did in a quote included above. Schein (2017) states that the learning culture must have in its DNA a learning gene in the sense that members must hold the shared assumption that learning is a good thing worth investing in (Schein, 2017 p. 344). The way of working in dialogues across LULAB projects indicates the development of what Schein (2017) refers to as a learning culture with mutual and structured feedback. Nevertheless, there are also some constraints. The presentations in the peer-groups tended to be focused more on what was done than on what was learned by 
what was done, and likewise for questions and feedback from peers which were focused on details in what happened more than on stimulating new thoughts. Thus, there is a variation in the degree of an 'inquiry stance' (Cochran-Smith \& Lytle, 2009). The vision of working together to bring about educational change grounded in the problems and the contexts of practice appears to a high degree to be aligned with the practitioners' beliefs. There are indications that the teacher educators are taking ownership (Cranton, 2011) exactly because LULAB projects are grounded in challenges identified from bottom-up. The constraints concerning an inquiry stance are more related to research skills and disposition (Tack \& Vanderlinde, 2014), in particular about deep analyses of what was learned from the projects. Thus, the challenge is not that inquiry is just implemented as stepwise procedures in a project as highlighted by Dana (2015) as a widespread challenge in professional inquiry. The practitioners in LULAB appear to value exactly the ongoing iterative collaborative work grounded in self-experienced problems. But looking forward, particular procedures to sharpen the focus on what is learned from the inquiry projects might be a help. Referring to Boyd and White (2017), sustained cycles of inquiry depend on manager support. Hence, there are some tensions to work on, where the leadership plays a central role. Teacher educators are well educated and value autonomy in their work (Hökkä et al., 2008), but it is crucial to find a balance in acknowledging this, but with constructive dialogues and feedback from the leadership. The strong autonomy in these consolidated groups of teacher educators is a driving force in the LULAB initiative, but can also lead to constraints concerning more overall organizational learning (Hökkä et al., 2008). One of the teacher educators refers to engagement and responsibility growing when you are creating yourself but also when you have a deep insight into the initiatives of others. The latter makes big demands for the leadership to secure a generalization in the organization based on the particulars from the projects.

Another related area with both potentials and constraints is the interplay between teacher educators and student teachers. The complex, nonlinear and interconnected processes of sense-making in a group (Weick \& Sutcliffe, 2001) can be seen both concerning knowledge sharing across projects, but also in the fact that the projects involve both teacher educators and student teachers. There are in the data so far indications that the cooperation focused on developing approaches in teacher education is stimulating the professional agency (Eteläpelto et al., 2013) of both groups, at least as they perceive it themselves. Furthermore, there appears to be a growing awareness along the processes of the particular role of student teachers as cooperative partners and co-developers as something distinctive in LULAB. However, it still appears to be the teacher educators that are considered to be 'the owners' of the projects both by themselves (implicitly) and by the student teachers. The initiative might benefit from a more explicit focus on how student teacher can be co-developers, as it appears to be valued by both student teachers and teacher educators when this happens.

\section{Conclusions}

The experiences from the first year of the LULAB initiative show experiments with a range of teacher educational approaches and themes in the professional inquiry projects. Examples are provided of research-informed teacher education practices of video-mediated reflections and simulations like microteaching, and also research-informed pedagogical practices like dialogic teaching. Findings from the first year of this longitudinal initiative show promising practices of a developing learning culture with mutual and structured feedback. Both teacher educators and student teachers emphasize their perceived professional outcomes. The student 
teachers refer in particular to insights from being invited into the machine room of teacher education and inspiration for their future work as teachers. The teacher educators refer in particular to the collaborative co-creation with colleagues, however, with a clear difference between those involved in a concrete LULAB project and those involved only through vicarious experiences. The reflections from the teacher educators furthermore indicate a growing awareness about the co-developing role of student teachers being something distinctive for LULAB. However, there are also challenges involved in developing a culture of inquiry, and particular procedures from the leadership to sharpen the focus on what is learned from the professional inquiry approach, and how practices can be spread and institutionalized could be recommended.

\section{References}

Barab, S., \& Squire, K. (2004). Design-based research: Putting a stake in the ground. Journal of the Learning Sciences, 13(1), 1-14.

Braun, V., \& Clarke, V. (2006). Using thematic analysis in psychology. Qualitative Research in Psychology, 3, 77-101.

Barnhart, T., \& van Es, E. (2015). Studying teacher noticing: Examining the relationship among pre-service science teachers' ability to attend, analyze, and respond to student thinking. Teaching and Teacher Education, 45, 83-93.

Boyd, P., \& White, E. (2017). Teacher educator professional inquiry in an age of accountability. In I. P. Boyd \& A. Szplit (Eds.), Teachers and teacher educators learning through inquiry: International perspectives (pp. 123-142). Attyka.

Brody, D. L., \& Hadar, L. L. (2015). Personal professional trajectories of novice and experienced teacher educators in a professional development community. Teacher Development, 19(2), 246-266.

Boreham, N., \& Morgan, C. (2007). A sociocultural analysis of organisational learning. Oxford Review of Education, 30(3), 307-325.

Cochran-Smith, M., \& Lytle, S. L. (2009). Inquiry as stance: Practitioner research for the next generation. Teachers College Press.

Cochran-Smith, M., \& Zeichner, K. M. (Eds.). (2005). Studying teacher education: The report of the AERA panel on research and teacher education. Lawrence Erlbaum Associates.

Cranton, P. (2011). A transformative perspective on the Scholarship of Teaching and Learning. Higher Education Research \& Development, 30(1), 75-86.

Creswell, J. W., \& Clark, V. L. P. (2018). Designing and conducting mixed methods research (3rd ed.). SAGE.

Czerniawski, G., Guberman, A., \& MacPhail, A. (2017). The professional development needs of higher education-based teacher educators: An international comparative needs analysis. European Journal of Teacher Education, 40(1), 127-140.

Dana, N. F. (2015). Understanding inquiry as stance: Illustration and analysis of one teacher researcher's work. Learning Landscapes, 8(2), 161-171.

Darling-Hammond, L. (2005). Policy and change: Getting beyond bureaucracy. In A. Heargreaves (Ed.), Extending educational change (pp. 362-387). Springer.

Dobber, M., Akkerman, S. F., Verloop, N., \& Vermunt, J. D. (2012). Student teachers' collaborative research: Small-scale research projects during teacher education. Teaching and Teacher Education, 28(4), 609-617.

Eteläpelto, A., Vähäsantanen, K., Hökkä, P., \& Paloniemi, S. (2013). What is agency? Conceptualizing professional agency at work. Educational Research Review, 10, 45-65.

Hadar, L., \& Brody, D. (2010). From isolation to symphonic harmony: Building a professional development community among teacher educators. Teaching and Teacher Education, 26, 1641-1651.

Hökkä, P., Rasku-Puttonen, H., \& Eteläpelto, A. (2008). Teacher educators' workplace learning: the interdependency between individual agency and social context. In S. Billett, C. Harteis, \& A. Eteläpelto (Eds.), Emerging perspectives in workplace learning. Sense Publishers.

Hökka, P., \& Eteläpelto, A. (2014). Seeking new perspectives on the development of teacher education: A study of the Finnish context. Journal of Teacher Education, 65(1), 39-52.

Klette, K., \& Hammerness, K. (2016). Conceptual framework for analyzing qualities in teacher education: Looking at features of teacher education from an international perspective. Acta Didactica Norge, 10(2), 26-52. 
Lunenberg, M., Dengerink, J., \& Korthagen, F. (2014). The professional teacher educator: Professional roles, behaviour, and development of teacher educators. Sense Publishers.

Mårtensson, K., Roxå, T., \& Olsson, T. (2011). Developing a quality culture through the Scholarship of Teaching and Learning. Higher Education Research \& Development, 30(1), 51-62.

Nielsen, B. L., Nielsen, O., \& Weissschädel, S. (2018). Teachers and student teachers co-creating: Relatedness, agency in supporting inclusion, and meaningful participation in research. In M. Sablić, A. Škugor \& I. Durdević Babić (Eds.), Conference Proceedings, 42nd ATEE Annual Conference 2017 (pp. 49-64). Association for Teacher Education in Europe (ATEE).

Nielsen, B. L. (Ed.) (2020). Lareruddannelsen i VIA-udviklingslaboratorium for god undervisning og uddannelse. Aarhus: VIA University College. https://www.via.dk/samarbejde/lulab

Policy document 1, Evaluation of teacher education in DK. (2018). https://ufm.dk/publikationer/2019/filer/ endelig-rapport_evaluering-af-laereruddannelsen.pdf

Policy document 2, Actions to develop a better teacher education in DK - 10 ambitions. (2018). https:// danskeprofessionshøjskoler.dk/10-ambitioner-skal-skabe-en-bedre-laereruddannelse/

Schein, E. H. (2017). Organizational culture and leadership (5th ed.). Wiley.

Staunæs, D., et al. (Eds.). (2014). Laringslaboratorier og-eksperimenter. Aarhus Universitetsforlag.

Stockero, S. L. (2008). Using a video-based curriculum to develop a reflective stance in prospective mathematics teachers. Journal of Mathematics Teacher Education, 11, 373-394.

Tack, H., \& Vanderlinde, R. (2014). Teacher educators' professional development: Towards a typology of teacher educators' researcherly disposition. British Journal of Educational Studies, 62(3), 297-315.

Wang, C. L., \& Ahmed, P. K. (2003). Organisational learning: A critical review. The Learning Organization, 10(1), 8-17.

Weick, K. (1995). Sensemaking in organizations. Sage.

Weick, K., \& Sutcliffe, K. M. (2001). Managing the unexpected. Jossey-Bass.

Publisher's Note Springer Nature remains neutral with regard to jurisdictional claims in published maps and institutional affiliations. 